\title{
Computational study of the reaction between chloroacetone and $\mathrm{OH}$ radical
}

\section{Nobuaki Tanaka*, Satoshi Yamagishi and Hiromasa Nishikiori}

Department of Environmental Science and Technology, Faculty of Engineering, Shinshu University, 4-17-1 Wakasato, Nagano 380-8553, Japan

* Corresponding author. Tel.: +81 262695527.

E-mail address: ntanaka@shinshu-u.ac.jp (N. Tanaka).

\begin{abstract}
In this study, the reaction of the chloroacetone with $\mathrm{OH}$ radical was studied theoretically using density functional theory (DFT) and transition state theory. The potential energy surface of the reaction was calculated at the CAM-B3LYP/6-311++G(2d,2p) and M06-2X/6-311++G(2d,2p) levels. We initially considered four possible reaction paths: (1) the hydrogen atom abstraction from chloroacetone by $\mathrm{OH}$ radical; (2) the addition of the $\mathrm{OH}$ radical to the carbonyl carbon; (3) chlorine atom abstraction; and (4) $\mathrm{S}_{\mathrm{N}} 2$ displacement. The conventional transition state theory was employed to calculate the rate constants. The hydrogen abstraction from the $-\mathrm{CH}_{2} \mathrm{Cl}$ group was found to be dominant. Since, the predicted total rate constant at the CAM-B3LYP/6-311++G(2d,2p) level was in good agreement with the experimental value at $298 \mathrm{~K}$, the level of theory used in this study to describe this reaction is appropriate.
\end{abstract}

Keywords: chloroacetone; OH radical; DFT; OH addition; H-atom abstraction 


\section{Introduction}

The $\mathrm{OH}$ radical plays a central role as an atmospheric oxidant. In the unpolluted troposphere, the $\mathrm{OH}$ radical is generated by the ozone photolysis-derived $\mathrm{O}\left({ }^{1} \mathrm{D}\right)$ reaction with water vapor, followed by the reaction with carbon monoxide or ozone to yield the hydroperoxy radical or with methane to yield the methylperoxy radical. Then, the hydroperoxy radical reacts with nitric oxide to reproduce the hydroxyl radical [1]. Additionally, in normal condition, the hydroxyl radical undergoes H-atom abstraction and/or addition reaction(s) with volatile organic compounds (VOCs). The VOC reaction leads to the formation of secondary organic aerosols (SOAs) [2], which affect the radiative balance [3].

Because of its important role in the upper troposphere and lower stratosphere [4], the $\mathrm{OH}$ radical reaction with acetone has been extensively studied both experimentally and theoretically [5, 6]. The abstraction product acetonyl radical is also an important intermediate species that yields peroxy radicals through the reaction with $\mathrm{O}_{2}[7,8]$. From the environmental point of view strongly linked with the depletion of the ozone layer, Carr et al. investigated the gas-phase reaction of the $\mathrm{OH}$ radical with halogenated acetones and determined the rate constants at $298 \mathrm{~K}$ [9]. However, since the product analysis has not been carried out yet, the detailed mechanism of chloroacetone oxidation remains uncertain. Computational studies can be useful for evaluating the possible mechanism of the oxidation. In this paper, we present the analysis of the reaction of the chloroacetone with the $\mathrm{OH}$ radical obtained by density functional theory (DFT) calculations. We consider the following possible reaction paths.

$$
\begin{aligned}
& \mathrm{CH}_{2} \mathrm{ClCOCH}_{3}+\mathrm{OH} \rightarrow \mathrm{CHClCOCH}_{3}+\mathrm{H}_{2} \mathrm{O} \\
& \mathrm{CH}_{2} \mathrm{ClCOCH}_{3}+\mathrm{OH} \rightarrow \mathrm{CH}_{2} \mathrm{ClCOCH}_{2}+\mathrm{H}_{2} \mathrm{O}
\end{aligned}
$$




$$
\begin{aligned}
& \mathrm{CH}_{2} \mathrm{ClCOCH}_{3}+\mathrm{OH} \rightarrow \mathrm{CH}_{2} \mathrm{ClCO}(\mathrm{OH}) \mathrm{CH}_{3} \\
& \mathrm{CH}_{2} \mathrm{ClCOCH}_{3}+\mathrm{OH} \rightarrow \mathrm{CH}_{2} \mathrm{COCH}_{3}+\mathrm{HOCl} \\
& \mathrm{CH}_{2} \mathrm{ClCOCH}_{3}+\mathrm{OH} \rightarrow \mathrm{CH}_{2}(\mathrm{OH}) \mathrm{COCH}_{3}+\mathrm{Cl}
\end{aligned}
$$

\section{Computational methods}

The equilibrium geometries of the reactants, transition states, products and complexes were optimized using the DFT method. Range-separated hybrid generalized gradient approximation (GGA) functional CAM-B3LYP [10] and hybrid meta-GGA functional M06-2X [11] were employed using the 6-311++G(2d,2p) basis set. The harmonic vibrational frequencies were calculated to confirm the predicted structures as local minima or transition states (one imaginary frequency) and to elucidate the zero-point vibrational energy (ZPE) corrections. The obtained transition states were confirmed as those connecting the investigational species by a calculation of the subsequent intrinsic reaction coordinates. All the calculations were performed using Gaussian 09 [12]. The spin-squared values were checked and the deviations from the doublet value of $\left\langle\mathrm{s}^{2}\right\rangle=0.75$ were found to be lower than $3.9 \%$. Therefore, the spin contamination was negligible for all the studied radical species.

The rate constants for the addition and abstraction reactions were estimated using the conventional thermodynamic formulation of transition state theory. The rate constant $k$ is given by

$$
k(T)=\kappa \frac{k_{\mathrm{B}} T}{h} \mathrm{e}^{-\Delta G^{\neq} / R T}
$$

where $k_{\mathrm{B}}$ is the Boltzmann constant, $T$ is the temperature, $h$ is Planck's constant, $\Delta G^{\neq}$is the Gibbs free energy of activation and $\kappa$ is the transmission coefficient. The tunneling effect was approximated using the Wigner correction [13]. In case the abstraction 
reaction proceeds via complex formation the rate constant $k$ is given by

$$
k(T)=\left(\frac{k_{a}}{k_{-a}}\right) k_{b}=K_{\mathrm{eq}} k_{b}
$$

where $k_{a}$ and $k_{-a}$ are the rate constants for the formation and dissociation of the complex, respectively, and $k_{b}$ corresponds to the consecutive abstraction reaction [14].

\section{Results and discussion}

Four types of reaction paths have been investigated for the $\mathrm{OH}+$ $\mathrm{CH}_{2} \mathrm{ClCOCH}_{3}$ reaction, namely (1) hydrogen atom abstraction, (2) $\mathrm{OH}$ addition, (3) chlorine atom abstraction and (4) $\mathrm{S}_{\mathrm{N}} 2$ displacement. In the gas phase, chloroacetone in the gauche form exists as a stable conformer by $299 \mathrm{~cm}^{-1}$ compared with that in the syn form [15]. Therefore, both gauche and syn forms were considered as reactants. The optimized structures of reactants, products, complexes and transition states are shown in Fig. 1. The selected bond lengths calculated at the (U)CAM-B3LYP/6-311++G(2d,2p) level of theory are listed in Table 1 . The energies and harmonic vibrational frequencies for the reactants, complexes, transition states and addition products are summarized in Tables S1 and S2, respectively. Table 2 lists the relative electronic energies, including the zero-point vibrational energies $\left(\Delta_{\mathrm{r}} E\right)$, relative enthalpies at $298 \mathrm{~K}\left(\Delta_{\mathrm{r}} H\right)$ and relative Gibbs energies at $298 \mathrm{~K}\left(\Delta_{\mathrm{r}} G\right)$ of the addition products and complexes to the isolated reactants. Because of the high activation energies, the contribution of the chlorine atom abstraction $\left(\Delta G^{\neq}=33.0\right.$ and $32.7 \mathrm{kcal} \mathrm{mol}^{-1}$ for $\mathrm{TS}_{\mathrm{Cl} \text {-abs } 1}$ and $\mathrm{TS}_{\mathrm{Cl}-\text { abs 3 }}$, respectively) and $\mathrm{S}_{\mathrm{N}} 2$ displacement $\left(\Delta G^{\neq}=48.3\right.$ and $34.2 \mathrm{kcal} \mathrm{mol}^{-1}$ for $\mathrm{TS}_{\text {gauche SN2 }}$ and $\mathrm{TS}_{\text {syn SN2}}$, respectively) should be negligible. Therefore, we will focus on the hydrogen abstraction and $\mathrm{OH}$ addition reactions. Fig. 2 represents the schematic Gibbs energy profiles of the relevant reaction pathways. 


\subsubsection{Hydrogen atom abstraction}

Table 3 lists the $\Delta E^{\neq}, \Delta H^{\ddagger}$ and $\Delta G^{\neq}$values for the H-atom abstraction reactions. The hydrogen abstraction reaction proceeds via two transition states for gauche-chloroacetone, $\mathrm{TS}_{\text {abs gauche } \mathrm{C} 1}$ and $\mathrm{TS}_{\text {abs gauche } \mathrm{C} 3}$, via other two transition states for syn-chloroacetone, $\mathrm{TS}_{\mathrm{abs} \mathrm{syn} \mathrm{C} 1}$ and $\mathrm{TS}_{\mathrm{abs} \text { syn } \mathrm{C} 3}$. In $\mathrm{TS}_{\mathrm{abs} \text { gauche } \mathrm{C} 1}$ and $\mathrm{TS}_{\mathrm{abs} \mathrm{syn} \mathrm{C} 1}$, the $\mathrm{OH}$ radical abstracts the hydrogen atom from the $-\mathrm{CH}_{2} \mathrm{Cl}$ group, while in $\mathrm{TS}_{\text {abs gauche } \mathrm{C} 3}$ and $\mathrm{TS}_{\text {abs syn C3 }}$ from the $-\mathrm{CH}_{3}$ group. (Intrinsic reaction coordinate IRC) calculations

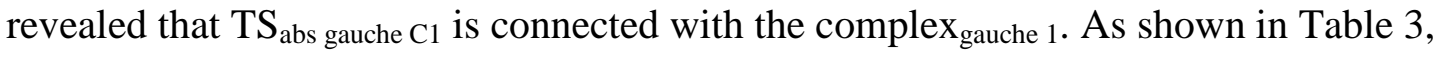
the breaking $\mathrm{C}-\mathrm{H}$ bond are elongated on average by $8.5 \%$ compared with the equilibrium $\mathrm{C}-\mathrm{H}$ bond length of chloroacetone, while the forming $\mathrm{O}-\mathrm{H}$ bonds are elongated on average by $44 \%$ compared with the $\mathrm{O}-\mathrm{H}$ bond of $\mathrm{H}_{2} \mathrm{O}$ at equilibrium. The reactant-like geometry is characteristic of an early transition state. The $\Delta G^{\neq}$values obtained using the UM06-2X functional are larger than those obtained using the UCAM-B3LYP functional in the range of $1.6\left(\mathrm{TS}_{\mathrm{abs} \text { gauche } \mathrm{C} 1}\right)$ to $2.3\left(\mathrm{TS}_{\text {abs gauche } \mathrm{C} 3}\right) \mathrm{kcal}$ $\mathrm{mol}^{-1}$. The $\Delta G^{\neq}$values of $\mathrm{TS}_{\text {abs gauche } \mathrm{C} 1}$ and $\mathrm{TS}_{\text {abs syn } \mathrm{C} 1}$ are relatively smaller than those of $\mathrm{TS}_{\text {abs gauche } \mathrm{C} 3}$ and $\mathrm{TS}_{\mathrm{abs} \text { syn } \mathrm{C} 3}$, respectively, mainly because of the differences in the $\mathrm{C}-$ $\mathrm{H}$ bond strength. At the (U)CAM-B3LYP/6-311++G(2d,2p) level, the difference in the $\mathrm{C}-\mathrm{H}$ bond dissociation enthalpy in the $-\mathrm{CH}_{2} \mathrm{Cl}$ group from that of the $-\mathrm{CH}_{3}$ group was calculated to be -6.3 and $-7.2 \mathrm{kcal} \mathrm{mol}^{-1}$ for the gauche- and syn-conformers, respectively. The $\mathrm{Cl}$ substitution lowered the bond strength of the $\mathrm{C}-\mathrm{H}$ bond of the $\mathrm{CH}_{2} \mathrm{Cl}$ group [9]. The rate constants for the $\mathrm{H}$-atom abstraction from the $-\mathrm{CH}_{2} \mathrm{Cl}$ group were calculated to be one order of magnitude larger than those from the $-\mathrm{CH}_{3}$ group. 


\subsection{2. $\mathrm{OH}$ addition}

The $\mathrm{OH}$ radical can attach to the carbon atom of the carbonyl group to form the $\mathrm{OH}$ adduct of chloroacetone. Depending on the different conformations of chloroacetone and the relative direction of the $\mathrm{O}-\mathrm{H}$ bond to the carbonyl group of chloroacetone, four stationary points (i.e. $\operatorname{add}_{\text {gauche 1, }} \operatorname{add}_{\text {gauche 1_2 }}$, add $\operatorname{gauche~} 2_{\text {and }} \operatorname{add}_{\text {syn }}$ ) were identified. In add gauche 1_2 and $\operatorname{add}_{\text {syn }}$, the $\mathrm{O}-\mathrm{H}$ bond points towards the $\mathrm{Cl}$ atom. The $\mathrm{O}-\mathrm{H}$ stretching vibrational frequencies of add $\operatorname{gauche~} 1 \_2_{2}$ and $\operatorname{add}_{\text {syn }}$ were red-shifted

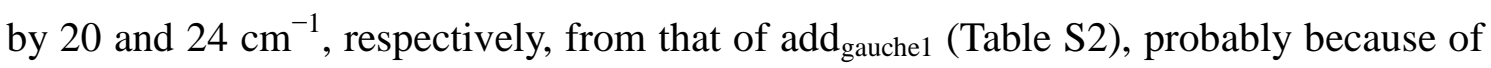
the presence of weak intramolecular hydrogen bonds. The second-order perturbation analysis of the natural bond orbital (NBO) Fock matrix [16] gave $n_{\mathrm{Cl}} \rightarrow \sigma_{\mathrm{OH}}^{*}$ interactions of 0.60 and $0.31 \mathrm{kcal} \mathrm{mol}^{-1}$ in magnitude for add gauche 1_2 and $\operatorname{add}_{\text {syn }}$, respectively, while the interactions for add gauche 1 and add gauche 2 were smaller than 0.25 kcal mol ${ }^{-1}$. The transition states $\mathrm{TS}_{\text {add gauche } 1}, \mathrm{TS}_{\text {add gauche } 2}$ and $\mathrm{TS}_{\text {add syn }}$ correspond to the

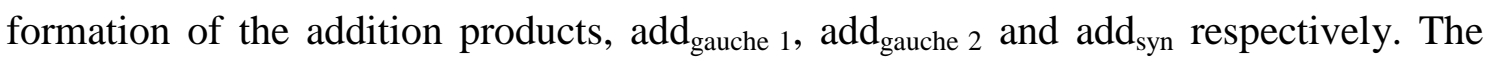
imaginary frequencies and relative energies of the transition states and distance ratios of $r_{\mathrm{C} \cdots \mathrm{OH}} / r_{\mathrm{C}-\mathrm{OH}}$ are summarized in Table 4 . The $\mathrm{C} \cdots \mathrm{OH}$ distances in the transition states are elongated by over 34\% compared with those of the addition products, indicating an early transition state. In contrast to the $\mathrm{H}$-atom abstraction reaction, the $\Delta G^{\neq}$values for the addition reaction calculated with the two methods differ by less than $0.4 \mathrm{kcal} \mathrm{mol}^{-1}$. The $\Delta G^{\ddagger}$ value for the addition of $\mathrm{OH}$ to syn-chloroacetone is found to be slightly smaller than that to gauche-chloroacetone. The barrier heights for the $\mathrm{OH}$ addition reaction are calculated to be higher than those for the H-atom abstraction reaction. A similar reactivity trend has been reported for acetone and fluoroacetone.

By taking the symmetry factor and Boltzmann ratio into consideration, with the 
CAM-B3LYP or M06-2X method, the total rate constant was calculated to be $3.24 \times$ $10^{-13}$ or $2.78 \times 10^{-14} \mathrm{~cm}^{3}$ molecule $\mathrm{s}^{-1}$ at $298 \mathrm{~K}$, respectively. The hydrogen abstraction from the $-\mathrm{CH}_{2} \mathrm{Cl}$ group was found to be dominant. The CAM-B3LYP value is in good agreement with the experimentally obtained value of $(4.2 \pm 0.8) \times 10^{-13} \mathrm{~cm}^{3}$ molecule $^{-1} \mathrm{~s}^{-1}$ [9]. The total rate constants calculated at the CAM-B3LYP/6-311++G(2d,2p) level over the temperature range 200-360 $\mathrm{K}$ are plotted in the Arrhenius form in Fig. 3. The two-parameter Arrhenius equation is

$$
k_{\text {total }}(T)=5.82 \times 10^{-15} \exp (1207 / T) \mathrm{cm}^{3} \text { molecule } \mathrm{s}^{-1} \mathrm{~s}^{-1}
$$

The Arrhenius plot of $k_{\text {total }}$ shows a slight deviation from linearity. Similar deviations were observed for the acetone $+\mathrm{OH}[5]$ and hydroxyacetone $+\mathrm{OH}$ [17] reactions. The three-parameter equation is

$$
k_{\text {total }}(T)=1.02 \times 10^{-22} \mathrm{~T}^{2.7} \exp (1924 / T) \mathrm{cm}^{3} \text { molecule }^{-1} \mathrm{~s}^{-1} .
$$

\section{Conclusions}

The reaction between the chloroacetone and $\mathrm{OH}$ radical has been studied theoretically using density functional theory and transition state theory. The potential energy surface of the reaction was calculated at the CAM-B3LYP/6-311++G(2d,2p) and M06-2X/6-311++G(2d,2p) levels, with which we analyzed two important reaction paths: (1) the hydrogen atom abstraction from chloroacetone by $\mathrm{OH}$ radical; and (2) the addition of the $\mathrm{OH}$ radical to the carbonyl carbon. The conventional transition state theory was employed to calculate the rate constants. The hydrogen abstraction from the $-\mathrm{CH}_{2} \mathrm{Cl}$ group was found to be dominant. The predicted total rate constant at the CAM-B3LYP/6-311++G(2d,2p) level is in good agreement with the experimental value at $298 \mathrm{~K}$. The temperature dependence of the total rate constant was fitted by the 
expression $k_{\text {total }}(T)=1.02 \times 10^{-22} \mathrm{~T}^{2.7} \exp (1924 / T) \mathrm{cm}^{3}$ molecule $\mathrm{s}^{-1}$.

\section{References}

[1] H. Levy II, Normal atomosphere: Large radical and formaldehyde concentrations predicted, Science, 173 (1971) 141.

[2] M. Kanakidou, J.H. Seinfeld, S.N. Pandis, I. Barnes, F.J. Dentener, M.C. Facchini, R. Van Dingenen, B. Ervens, A. Nenes, C.J. Nielsen, E. Swietlicki, J.P. Putaud, Y. Balkanski, S. Fuzzi, J. Horth, G.K. Moortgat, R. Winterhalter, C.E.L. Myhre, K. Tsigaridis, E. Vignati, E.G. Stephanou, J. Wilson, Organic aerosol and global climate modelling: a review, Atmos Chem Phys, 5 (2005) 1053-1123.

[3] P. Forster, V. Ramaswamy, P. Artaxo, T. Berntsen, R. Betts, D.W. Fahey, J. Haywood, J. Lean, D.C. Lowe, G. Myhre, J. Nganga, R. Prinn, G. Raga, M. Schulz, R.V. Dorland, Changes in Atmospheric Constituents and in Radiative Forcing, in: S. Solomon, D. Qin, M. Manning, Z. Chen, M. Marquis, K.B. Averyt, M.Tignor, H.L. Miller (Eds.) Climate Change 2007: The Physical Science Basis. Contribution of Working Group I to the Fourth Assessment Report of the Intergovernmental Panel on Climate Change, Cambridge University Press, Cambridge, United Kingdom and New York, NY, USA, 2007.

[4] H.B. Singh, M. Kanakidou, P.J. Crutzen, D.J. Jacob, High-concentrations and photochemical fate of oxygenated hydrocarbons in the global troposphere, Nature, 378 (1995) 50-54.

[5] T. Yamada, P.H. Taylor, A. Goumri, P. Marshall, The reaction of $\mathrm{OH}$ with acetone and acetone-d(6) from 298 to 832 K: Rate coefficients and mechanism, J Chem Phys, 119 (2003) 10600-10606.

[6] M. Wollenhaupt, S.A. Carl, A. Horowitz, J.N. Crowley, Rate coefficients for reaction of OH with acetone between 202 and 395 K, J Phys Chem A, 104 (2000) 2695-2705.

[7] K. Imrik, E. Farkas, G. Vasvari, I. Szilagyi, D. Sarzynski, S. Dobe, T. Berces, F. Marta, Laser spectrometry and kinetics of selected elementary reactions of the acetonyl radical, Phys Chem Chem Phys, 6 (2004) 3958-3968.

[8] M. Hassouna, E. Delbos, P. Devolder, B. Viskolcz, C. Fittschen, Rate and equilibrium constant of the reaction of 1-methylvinoxy radicals with $\mathrm{O}_{2}$ : $\mathrm{CH}_{3} \mathrm{COCH}_{2}+\mathrm{O}_{2} \rightarrow \mathrm{CH}_{3} \mathrm{COCH}_{2} \mathrm{O}_{2}$, J Phys Chem A, 110 (2006) 6667-6672.

[9] S. Carr, D.E. Shallcross, C. Canosa-Mas, J.C. Wenger, H.W. Sidebottom, J.J. Treacy, R.P. Wayne, A kinetic and mechanistic study of the gas-phase reactions of $\mathrm{OH}$ radicals and $\mathrm{Cl}$ atoms with some halogenated acetones and their atmospheric implications, Phys 
Chem Chem Phys, 5 (2003) 3874-3883.

[10] T. Yanai, D.P. Tew, N.C. Handy, A new hybrid exchange-correlation functional using the Coulomb-attenuating method (CAM-B3LYP), Chem Phys Lett, 393 (2004) 51-57.

[11] D.G. Truhlar, Y. Zhao, The M06 suite of density functionals for main group thermochemistry, thermochemical kinetics, noncovalent interactions, excited states, and transition elements: two new functionals and systematic testing of four M06-class functionals and 12 other functionals, Theor Chem Acc, 120 (2008) 215-241.

[12] M.J. Frisch, G.W. Trucks, H.B. Schlegel, G.E. Scuseria, M.A. Robb, J.R. Cheeseman, G. Scalmani, V. Barone, B. Mennucci, G.A. Petersson, H. Nakatsuji, M. Caricato, X. Li, H.P. Hratchian, A.F. Izmaylov, J. Bloino, G. Zheng, J.L. Sonnenberg, M. Hada, M. Ehara, K. Toyota, R. Fukuda, J. Hasegawa, M. Ishida, T. Nakajima, Y. Honda, O. Kitao, H. Nakai, T. Vreven, J. Montgomery, J. A., J.E. Peralta, F. Ogliaro, M. Bearpark, J.J. Heyd, E. Brothers, K.N. Kudin, V.N. Staroverov, R. Kobayashi, J. Normand, K. Raghavachari, A. Rendell, J.C. Burant, S.S. Iyengar, J. Tomasi, M. Cossi, N. Rega, N.J. Millam, M. Klene, J.E. Knox, J.B. Cross, V. Bakken, C. Adamo, J. Jaramillo, R. Gomperts, R.E. Stratmann, O. Yazyev, A.J. Austin, R. Cammi, C. Pomelli, J.W. Ochterski, R.L. Martin, K. Morokuma, V.G. Zakrzewski, G.A. Voth, P. Salvador, J.J. Dannenberg, S. Dapprich, A.D. Daniels, Ö. Farkas, J.B. Foresman, J.V. Ortiz, J. Cioslowski, D.J. Fox, Gaussian 09, Revision B.01, Gaussian, Inc., Wallingford, 2010.

[13] E. Wigner, Crossing of potential thresholds in chemical reactions, Z Phys Chem, B19 (1932) 203-216.

[14] D.L. Singleton, R.J. Cvetanovic, Temperature dependence of the reactions of oxygen atoms with olefins, J Am Chem Soc, 98 (1976) 6812-6819.

[15] C.T. Au, Y.Q. Zhang, C.F. Ng, H.L. Wan, Oxidative coupling of methane over $\mathrm{LaF}_{3} / \mathrm{La}_{2} \mathrm{O}_{3}$ catalysts, Catal Lett, 23 (1994) 377-386.

[16] A.E. Reed, L.A. Curtiss, F. Weinhold, Intermolecular interaction from a natural bond orbital, donor-acceptor viewpoint, Chem Rev, 88 (1988) 899-926.

[17] A. Galano, Theoretical study on the reaction of tropospheric interest: Hydroxyacetone plus OH. Mechanism and kinetics, J Phys Chem A, 110 (2006) 9153-9160.

\section{Figure captions}

Fig. 1. Optimized structures of the reactants, complexes, $\mathrm{OH}$ addition products, transition states and abstraction products calculated at the 
(U)CAM-B3LYP/6-311++G(2d,2p) level of theory.

Fig. 2. Schematic Gibbs energy profiles for the $\mathrm{OH}$ addition and H-atom abstraction reactions of chloroacetone $+\mathrm{OH}$ calculated at the (U)CAM-B3LYP/6-311++G(2d,2p) level of theory.

Fig. 3. Arrhenius plot of the total rate constant in the temperature range 200-360 K. Solid line: two-parameter fitting. Dashed line: three-parameter fitting. 


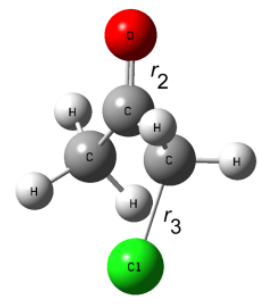

gauche-chloroacetone

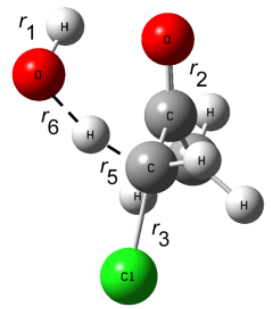

$\mathrm{TS}_{\text {abs gauche } \mathrm{C} 1}$

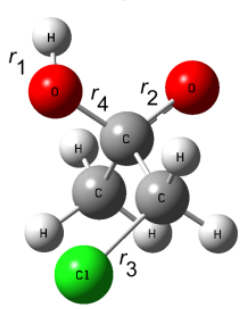

add $_{\text {gauche } 1}$

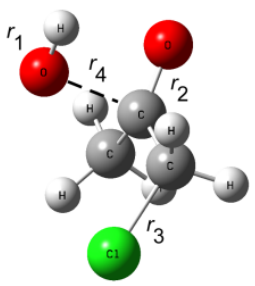

TS add gauche 1

- ${ }^{r_{1}} r_{7}$

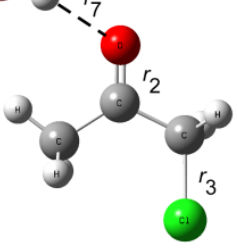

complex gauche 2

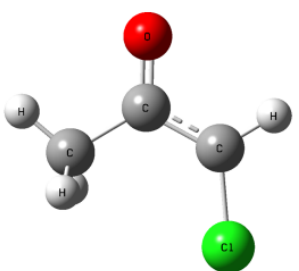

anti- $\mathrm{CH}_{3} \mathrm{COCHCl}$

Fig. 1

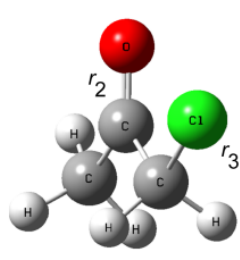

syn-chloroacetone

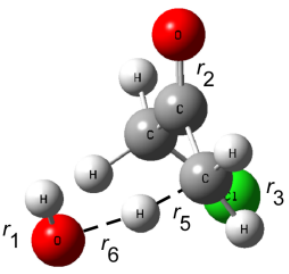

TS abs gauche C3

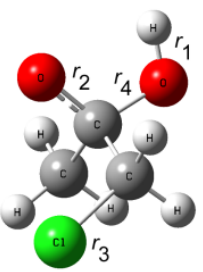

add $_{\text {gauche } 2}$

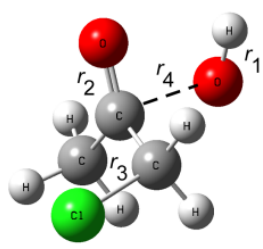

TS add gauche 2

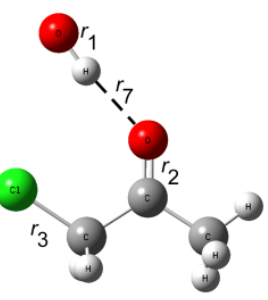

complex $_{\text {syn }}$

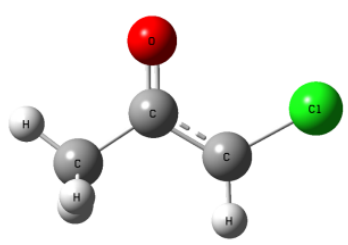

syn- $\mathrm{CH}_{3} \mathrm{COCHCl}$

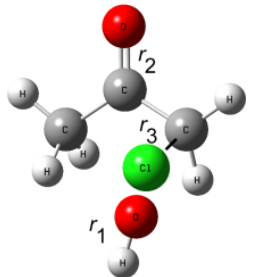

$\mathrm{TS}_{\text {Cl-abs } 1}$

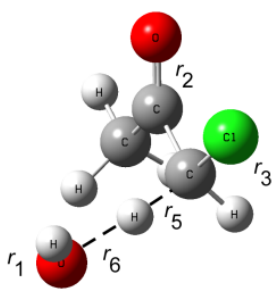

TS ${ }_{\text {abs syn }}$ 1 1

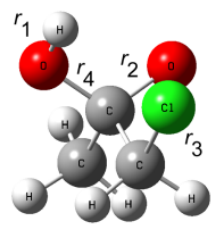

$\operatorname{add}_{\text {syn }}$

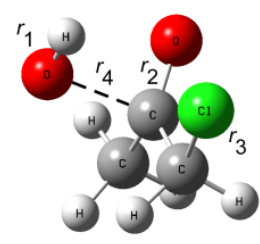

TS add syn

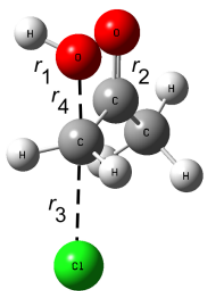

TS gauche SN2

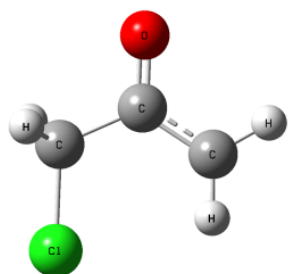

anti- $\mathrm{CH}_{2} \mathrm{ClCOCH}_{2}$

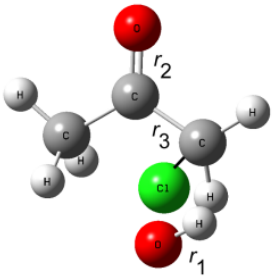

$\mathrm{TS}_{\text {Cl-abs } 3}$

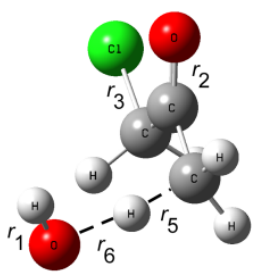

$\mathrm{TS}_{\text {abs syn C3 }}$

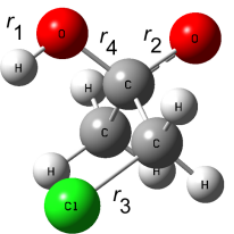

add gauche 1_2

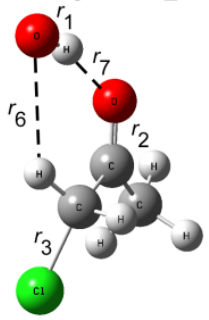

complex gauche 1

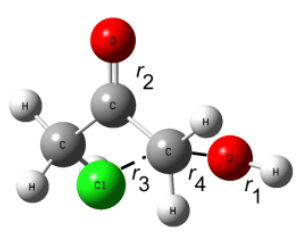

$\mathrm{TS}_{\text {syn SN2 }}$

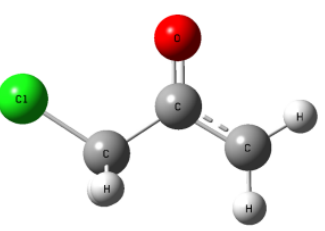

syn- $\mathrm{CH}_{2} \mathrm{CICOCH}_{2}$ 


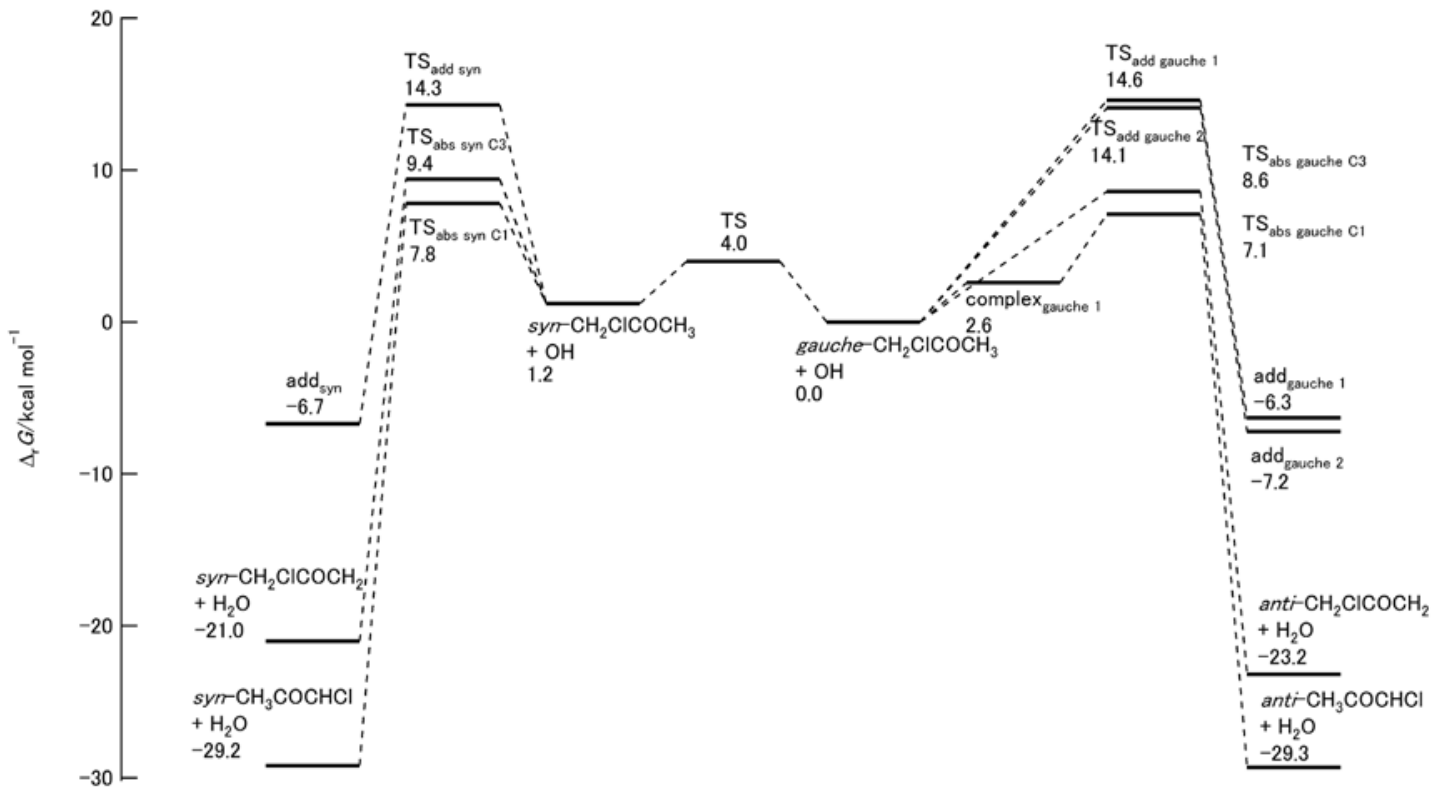

Fig. 2

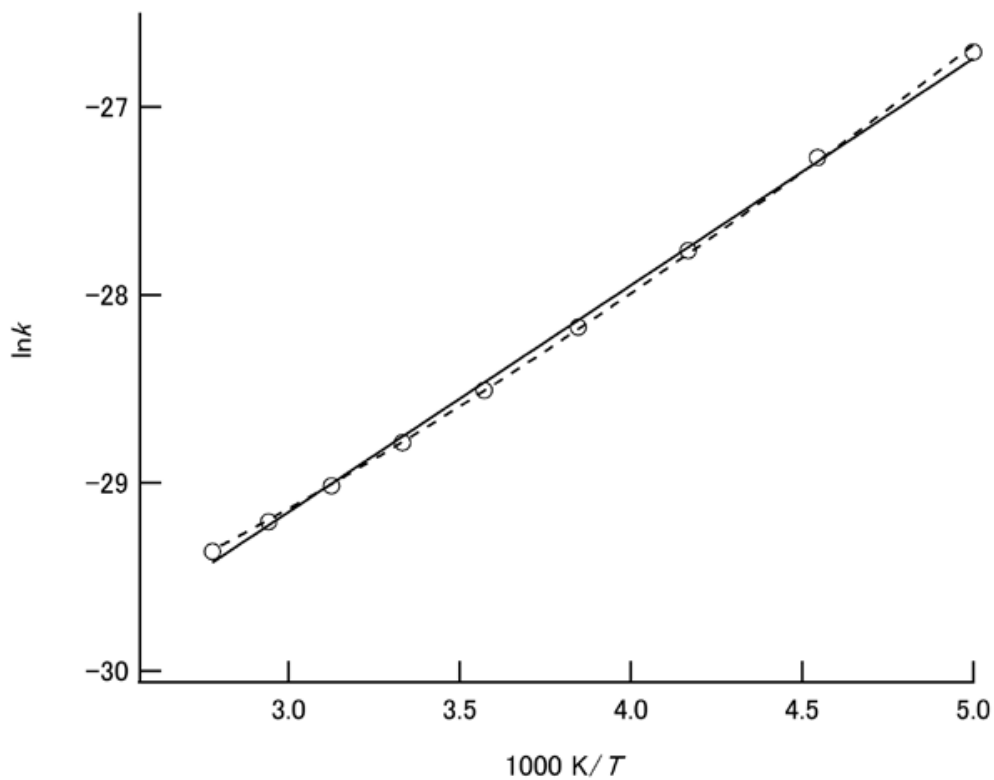

Fig. 3 


\section{Table 1}

Selected geometrical parameters $(\AA)$ optimized at the (U)CAM-B3LYP/6-311++G(2d,2p) level .

\begin{tabular}{|c|c|c|c|c|c|c|c|}
\hline species & $r_{1}$ & $r_{2}$ & $r_{3}$ & $r_{4}$ & $r_{5}$ & $r_{6}$ & $r_{7}$ \\
\hline gauche-chloroacetone & & 1.204 & 1.792 & & & & \\
\hline syn-chloroacetone & & 1.198 & 1.774 & & & & \\
\hline $\mathrm{OH}$ & 0.971 & & & & & & \\
\hline $\mathrm{H}_{2} \mathrm{O}$ & 0.959 & & & & & & \\
\hline $\mathrm{TS}_{\text {abs gauche } \mathrm{C} 1}$ & 0.972 & 1.207 & 1.761 & & 1.196 & 1.330 & \\
\hline $\mathrm{TS}_{\mathrm{abs} \text { gauche C3 }}$ & 0.970 & 1.205 & 1.796 & & 1.186 & 1.374 & \\
\hline $\mathrm{TS}_{\mathrm{abs} \text { syn } \mathrm{C} 1}$ & 0.971 & 1.199 & 1.753 & & 1.159 & 1.436 & \\
\hline $\mathrm{TS}_{\mathrm{abs} \text { syn C3}}$ & 0.970 & 1.200 & 1.773 & & 1.187 & 1.365 & \\
\hline add $_{\text {gauche } 1}$ & 0.961 & 1.343 & 1.786 & 1.405 & & & \\
\hline $\operatorname{add}_{\text {gauche 1_2 }}$ & 0.962 & 1.338 & 1.795 & 1.405 & & & \\
\hline add $_{\text {gauche } 2}$ & 0.961 & 1.334 & 1.782 & 1.419 & & & \\
\hline $\operatorname{add}_{\text {syn }}$ & 0.963 & 1.353 & 1.795 & 1.402 & & & \\
\hline $\mathrm{TS}_{\text {add gauche } 1}$ & 0.971 & 1.247 & 1.787 & 1.915 & & & \\
\hline $\mathrm{TS}_{\text {add gauche } 2}$ & 0.971 & 1.247 & 1.800 & 1.916 & & & \\
\hline $\mathrm{TS}_{\text {add syn }}$ & 0.972 & 1.239 & 1.781 & 1.921 & & & \\
\hline $\mathrm{TS}_{\mathrm{Cl}-\mathrm{abs} 1}$ & 0.965 & 1.215 & 2.265 & & & & \\
\hline $\mathrm{TS}_{\mathrm{Cl}-\mathrm{abs} 3}$ & 0.966 & 1.216 & 2.264 & & & & \\
\hline $\mathrm{TS}_{\text {gauche SN2 }}$ & 0.969 & 1.231 & 2.429 & 1.771 & & & \\
\hline $\mathrm{TS}_{\text {syn SN2 }}$ & 0.968 & 1.199 & 2.138 & 1.845 & & & \\
\hline complex gauche 1 & 0.983 & 1.211 & 1.789 & & & 2.664 & 1.873 \\
\hline complex gauche 2 & 0.982 & 1.210 & 1.788 & & & & 1.876 \\
\hline complex $_{\text {syn }}$ & 0.979 & 1.203 & 1.773 & & & & 1.931 \\
\hline
\end{tabular}

${ }^{a}$ Geometrical parameters are shown in Fig. 1. 
Table 2

Thermochemical parameters $\left(\mathrm{kcal} \mathrm{mol}^{-1}\right)$ of products.

\begin{tabular}{|c|c|c|c|c|}
\hline stationary point & functional & $\Delta_{\mathrm{r}} \underline{\underline{E}}$ & $\Delta_{\mathrm{r}} \underline{H}$ & $\Delta_{\mathrm{r}} \underline{G}$ \\
\hline \multirow[t]{2}{*}{$\operatorname{add}_{\text {gauche } 1}$} & UCAM-B3LYP & -16.2 & -17.5 & -6.3 \\
\hline & UM06-2X & -18.4 & -19.8 & -8.5 \\
\hline \multirow{2}{*}{ add $\operatorname{agauche~1\_ 2~}_{2}$} & UCAM-B3LYP & -15.8 & -17.3 & -5.6 \\
\hline & UM06-2X & -18.5 & -19.9 & -8.5 \\
\hline \multirow[t]{2}{*}{ add $_{\text {gauche } 2}$} & UCAM-B3LYP & -17.0 & -18.2 & -7.2 \\
\hline & UM06-2X & -19.0 & -20.3 & -9.2 \\
\hline \multirow[t]{2}{*}{$\operatorname{add}_{\text {syn }}$} & UCAM-B3LYP & -16.8 & -18.2 & -6.7 \\
\hline & UM06-2X & -19.4 & -20.9 & -9.5 \\
\hline \multirow[t]{2}{*}{ complex gauche 1} & UCAM-B3LYP & -4.9 & -5.3 & 2.6 \\
\hline & UM06-2X & -4.9 & -5.3 & 2.5 \\
\hline \multirow[t]{2}{*}{ complex gauche 2} & UCAM-B3LYP & -4.6 & -5.0 & 2.2 \\
\hline & UM06-2X & -4.8 & -5.3 & 2.5 \\
\hline complex $_{\underline{\text { syn }}}$ & UCAM-B3LYP & -3.8 & -4.0 & 3.3 \\
\hline
\end{tabular}




\section{Table 3}

Calculated imaginary frequencies, ratios of $\mathrm{HO}$ and $\mathrm{CH}$ distances, and thermochemical parameters $\left(\mathrm{kcal}^{\mathrm{mol}}{ }^{-1}\right)$ of the transition states and rate constants for abstraction reactions.

\begin{tabular}{|c|c|c|c|c|c|c|c|c|}
\hline stationary point & functional & $v / \mathrm{cm}^{-1}$ & $r_{H_{\mathrm{H}} \cdots \mathrm{OH}} / r_{{ }_{\mathrm{H}-\mathrm{OH}}}$ & $r_{\mathrm{C}} \cdots \mathrm{H}_{\mathrm{H}} / r_{\mathrm{C}-\mathrm{H}_{-}}$ & $\Delta E^{\neq}$ & $\Delta H^{\neq}$ & $\Delta G^{\neq}$ & $\mathrm{k} / \mathrm{cm}^{3}$ molecule ${ }^{-1} \mathrm{~s}^{-1}$ \\
\hline \multirow[t]{2}{*}{$\mathrm{TS}_{\text {abs gauche } \mathrm{C} 1}$} & UCAM-B3LYP & $1112 \mathrm{i}$ & 1.39 & 1.10 & -1.7 & -2.6 & 7.1 & $1.46 \times 10^{-13}$ \\
\hline & UM06-2X & $1378 \mathrm{i}$ & 1.40 & 1.10 & 0.1 & -0.8 & 8.7 & $1.26 \times 10^{-14}$ \\
\hline \multirow[t]{2}{*}{$\mathrm{TS}_{\text {abs gauche } \mathrm{C} 3}$} & UCAM-B3LYP & $784 \mathrm{i}$ & 1.43 & 1.09 & 0.7 & 0.0 & 8.6 & $8.08 \times 10^{-15}$ \\
\hline & UM06-2X & $1133 i$ & 1.45 & 1.08 & 3.1 & 2.3 & 10.9 & $2.18 \times 10^{-16}$ \\
\hline \multirow[t]{2}{*}{$\mathrm{TS}_{\text {abs syn C1 }}$} & UCAM-B3LYP & $462 \mathrm{i}$ & 1.50 & 1.07 & -1.4 & -2.0 & 6.6 & $1.79 \times 10^{-13}$ \\
\hline & UM06-2X & $989 \mathrm{i}$ & 1.48 & 1.07 & 0.3 & -0.4 & 8.3 & $1.76 \times 10^{-14}$ \\
\hline \multirow[t]{2}{*}{$\mathrm{TS}_{\text {abs syn C3 }}$} & UCAM-B3LYP & $815 i$ & 1.42 & 1.09 & 0.1 & -0.7 & 8.2 & $1.67 \times 10^{-14}$ \\
\hline & UM06-2X & $1151 \mathrm{i}$ & 1.44 & 1.08 & 2.2 & 1.3 & 10.2 & $7.91 \times 10^{-16}$ \\
\hline
\end{tabular}




\section{Table 4}

Calculated imaginary frequencies, CO distance ratios and thermochemical parameters $\left(\mathrm{kcal} \mathrm{mol}^{-1}\right)$ of the transition states and rate constants for addition reactions.

\begin{tabular}{|c|c|c|c|c|c|c|c|}
\hline stationary point & functional & $v / \mathrm{cm}^{-1}$ & $r_{\mathrm{C}} \cdots \mathrm{OH} / r_{\mathrm{C}-\mathrm{OH}}$ & $\Delta E^{\neq}$ & $\Delta H^{\neq}$ & $\Delta G^{\neq}$ & $\mathrm{k} / \mathrm{cm}^{3}$ molecule ${ }^{-1} \mathrm{~s}^{-1}$ \\
\hline \multirow[t]{2}{*}{$\mathrm{TS}_{\text {add gauche } 1}$} & UCAM-B3LYP & $458 \mathrm{i}$ & 1.36 & 4.9 & 3.7 & 14.6 & $2.29 \times 10^{-19}$ \\
\hline & UM06-2X & $614 \mathrm{i}$ & 1.35 & 5.6 & 4.5 & 15.0 & $1.54 \times 10^{-19}$ \\
\hline \multirow[t]{2}{*}{$\mathrm{TS}_{\text {add gauche } 2}$} & UCAM-B3LYP & $454 i$ & 1.35 & 4.4 & 3.3 & 14.1 & $6.19 \times 10^{-19}$ \\
\hline & UM06-2X & $622 \mathrm{i}$ & 1.34 & 5.2 & 4.1 & 14.4 & $3.62 \times 10^{-19}$ \\
\hline \multirow[t]{2}{*}{$\mathrm{TS}_{\text {add syn }}$} & UCAM-B3LYP & $460 \mathrm{i}$ & 1.30 & 3.3 & 2.0 & 13.2 & $2.78 \times 10^{-18}$ \\
\hline & UM06-2X & $627 i$ & 1.35 & 3.9 & 2.5 & 13.6 & $1.63 \times 10^{-18}$ \\
\hline
\end{tabular}




\section{Table S1}

Zero-point corrected energies (Hartree) of the reactants, complexes, OH addition products, transition states and abstraction products calculated at the (U)CAM-B3LYP/6-311++G(2d,2p) level.

\begin{tabular}{|c|c|}
\hline species & energies \\
\hline gauche-chloroacetone & -652.671403 \\
\hline syn-chloroacetone & -652.669505 \\
\hline $\mathrm{OH}$ & -75.729766 \\
\hline $\mathrm{H}_{2} \mathrm{O}$ & -76.412417 \\
\hline $\mathrm{TS}_{\text {abs gauche } \mathrm{C} 1}$ & -728.403822 \\
\hline $\mathrm{TS}_{\text {abs gauche } \mathrm{C} 3}$ & -728.399987 \\
\hline $\mathrm{TS}_{\text {abs syn C1 }}$ & -728.401438 \\
\hline $\mathrm{TS}_{\text {abs syn } \mathrm{C} 3}$ & -728.399034 \\
\hline add $_{\text {gauche } 1}$ & -728.427044 \\
\hline add gauche 1_2 & -728.426395 \\
\hline add $_{\text {gauche } 2}$ & -728.428244 \\
\hline $\operatorname{add}_{\text {syn }}$ & -728.427978 \\
\hline $\mathrm{TS}_{\text {add gauche } 1}$ & -728.393355 \\
\hline $\mathrm{TS}_{\text {add gauche } 2}$ & -728.394103 \\
\hline $\mathrm{TS}_{\text {add syn }}$ & -728.394016 \\
\hline $\mathrm{TS}_{\mathrm{Cl} \text {-abs } 1}$ & -728.360957 \\
\hline $\mathrm{TS}_{\mathrm{Cl} \text {-abs } 3}$ & -728.361451 \\
\hline $\mathrm{TS}_{\text {gauche SN2 }}$ & -728.339822 \\
\hline $\mathrm{TS}_{\text {syn SN2 }}$ & -728.360809 \\
\hline complex gauche 1 & -728.408952 \\
\hline complex gauche 2 & -728.408507 \\
\hline complex $_{\text {syn }}$ & -728.407154 \\
\hline anti- $\mathrm{CH}_{3} \mathrm{COCHCl}$ & -652.035505 \\
\hline syn- $\mathrm{CH}_{3} \mathrm{COCHCl}$ & -652.033714 \\
\hline anti- $\mathrm{CH}_{2} \mathrm{ClCOCH}_{2}$ & -652.025351 \\
\hline syn- $\mathrm{CH}_{2} \mathrm{ClCOCH}_{2}$ & -652.021976 \\
\hline
\end{tabular}




\section{Table S2}

Harmonic vibrational frequencies of the stationary points calculated at the (U)CAM-B3LYP/6-311++G(2d,2p) level.

\begin{tabular}{|c|c|}
\hline species & frequencies $/ \mathrm{cm}^{-1}$ \\
\hline gauche-chloroacetone & $\begin{array}{l}\text { 23, 169, 221, 405, 473, 518, 745, 830, 1013, 1056, 1209, } \\
\text { 1265, 1299, 1413, 1458, 1473, 1483, 1822, 3075, 3116, } \\
\text { 3133, 3182, } 3188\end{array}$ \\
\hline syn-chloroacetone & $\begin{array}{l}\text { 35, 98, 212, 355, 467, 583, 781, 828, 856, 978, 1057, } \\
\text { 1193, 1222, 1340, 1408, 1458, 1478, 1490, 1849, 3066, } \\
\text { 3101, 3124, 3149, } 3177\end{array}$ \\
\hline $\mathrm{OH}$ & 3756 \\
\hline $\mathrm{H}_{2} \mathrm{O}$ & 1634, 3861, 3962 \\
\hline $\mathrm{TS}_{\text {abs gauche } \mathrm{C} 1}$ & $\begin{array}{l}\text { 1112i, 30, 120, 168, 223, 385, 409, 479, 529, 556, 757, } \\
812,887,922,1012,1071,1241,1277,1282,1411, \\
1472,1480,1512,1798,3075,3134,3154,3184,3741\end{array}$ \\
\hline $\mathrm{TS}_{\text {abs gauche C3 }}$ & $\begin{array}{l}\text { 784i, 24, 63, 76, 166, 208, 335, 399, 500, 549, 749, 817, } \\
841,855,979,1031,1156,1206,1267,1297,1316, \\
1369,1467,1479,1807,3118,3129,3202,3212,3780\end{array}$ \\
\hline $\mathrm{TS}_{\text {abs syn C1 }}$ & $\begin{array}{l}\text { 462i, 40, 66, 102, 126, 145, 214, 357, 480, 583, 698, 790, } \\
837,875,983,1072,1186,1191,1312,1340,1410, \\
1480,1564,1839,3068,3128,3140,3179,3771\end{array}$ \\
\hline $\mathrm{TS}_{\text {abs syn C3 }}$ & $\begin{array}{l}\text { 815i, 35, 48, 96, 163, 211, 327, 377, 475, 579, 779, 788, } \\
857,867,966,992,1105,1197,1224,1287,1350,1371 \text {, } \\
\text { 1458, 1465, 1829, 3100, 3113, 3150, 3202, } 3780\end{array}$ \\
\hline add $_{\text {gauche } 1}$ & $\begin{array}{l}\text { 99, 144, 202, 229, 307, 343, 433, 475, 559, 744, 805, } \\
888,923,968,1043,1082,1174,1274,1307,1340, \\
1394,1476,1483,1500,3087,3139,3172,3181,3208, \\
3865\end{array}$ \\
\hline $\operatorname{add}_{\text {gauche 1_2 }}$ & $\begin{array}{l}\text { 114, 202, 225, 274, 3324, 337, 432, 476, 566, 740, 793, } \\
886,943,959,1045,1102,1182,1258,1293,1320, \\
1400,1477,1484,1502,3085,3141,3166,3182,3212, \\
3845\end{array}$ \\
\hline add $_{\text {gauche } 2}$ & $\begin{array}{l}\text { 92, 129, 202, 219, 319, 338, 396, 447, 557, 754, 812, } \\
\text { 893, 929, 957, 1046, 1100, 1160, 1213, 1311, 1318, } \\
\text { 1403, 1477, 1486, 1502, 3089, 3136, 3168, 3196, 3202, } \\
3866\end{array}$ \\
\hline
\end{tabular}




\begin{tabular}{|c|c|}
\hline $\operatorname{add}_{\text {syn }}$ & $\begin{array}{l}\text { 104, 184, 198, 270, 320, 331, 436, 497, 543, 763, 817, } \\
889,922,955,1026,1118,1181,1274,1301,1346, \\
1404,1471,1485,1504,3088,3135,3180,3207,3841\end{array}$ \\
\hline $\mathrm{TS}_{\text {add gauche } 1}$ & $\begin{array}{l}\text { 458i, 77, 163, 200, 247, 261, 295, 427, 450, 500, 758, } \\
\text { 823, 838, 866, 1017, 1033, 1192, 1273, 1309, 1416, } \\
\text { 1465, 1469, 1488, 1564, 3074, 3113, 3156, 3195, 3196, } \\
3765\end{array}$ \\
\hline $\mathrm{TS}_{\text {add gauche } 2}$ & $\begin{array}{l}\text { 454i, 79, 169, 172, 215, 238, 295, 388, 482, 536, 737, } \\
\text { 818, 835, 916, 1013, 1042, 1168, 1269, 1307, 1416, } \\
\text { 1471, 1478, 1492, 1562, 3084, 3144, 3152, 3187, 3216, } \\
3766\end{array}$ \\
\hline $\mathrm{TS}_{\text {add syn }}$ & $\begin{array}{l}\text { 460i, 96, 152, 186, 238, 284, 354, 366, 451, 566, 773, } \\
\text { 833, 856, 884, 983, 1036, 1200, 1207, 1344, 1412, 1463, } \\
\text { 1472, 1492, 1587, 3074, 3109, 3144, 3181, 3185, } 3754\end{array}$ \\
\hline $\mathrm{TS}_{\mathrm{Cl} \text {-abs } 1}$ & $\begin{array}{l}\text { 421i, 46, 68, 88, 94, 140, 158, 377, 429, 525, 564, 690, } \\
825,910,926,1057,1086,1121,1268,1412,1467, \\
1484,1489,1713,3069,3129,3174,3179,3284,3826\end{array}$ \\
\hline $\mathrm{TS}_{\text {Cl-abs } 3}$ & $\begin{array}{l}\text { 421i, 36, 74, 93, 96, 145, 177, 378, 431, 526, 567, 688, } \\
\text { 826, 912, 926, 1058, 1086, 1126, 1268, 1414, 1467, } \\
1484,1489,1711,3069,3129,3175,3179,3285,3822\end{array}$ \\
\hline $\mathrm{TS}_{\text {gauche SN2 }}$ & $\begin{array}{l}\text { 619i, 72, 201, 219, 253, 264, 387, 461, 491, 573, 611, } \\
\text { 820, 834, 868, 1007, 1043, 1101, 1107, 1298, 1395, } \\
\text { 1411, 1438, 1446, 1668, 3075, 3136, 3180, 3230, 3344, } \\
3787\end{array}$ \\
\hline $\mathrm{TS}_{\text {syn SN2 }}$ & $\begin{array}{l}\text { 981i, 91, 118, 131, 158, 180, 194, 303, 394, 532, 584, } \\
\text { 796, 869, 897, 1060, 1064, 1073, 1136, 1253, 1405, } \\
\text { 1416, 1484, 1487, 1838, 3068, 3076, 3140, 3183, 3281, } \\
3796\end{array}$ \\
\hline complex gauche 1 & $\begin{array}{l}\text { 41, 43, 63, 163, 175, 226, 405, 441, 483, 532, 624, 751, } \\
836,850,1017,1057,1214,1279,1314,1415,1456, \\
1470,1482,1796,3076,3108,3134,3179,3185,3554\end{array}$ \\
\hline complex gauche 2 & $\begin{array}{l}\text { 19, 33, 39, 163, 167, 227, 421, 468, 481, 527, 593, 751, } \\
829,851,1016,1057,1216,1275,1304,1418,1455, \\
1473,1483,1801,3075,3117,3134,3178,3184,3571\end{array}$ \\
\hline complex $_{\text {syn }}$ & $\begin{array}{l}27,46,56,101,145,221,362,426,467,530,591,787, \\
827,862,989,1057,1200,1226,1346,1412,1455,\end{array}$ \\
\hline
\end{tabular}


1477, 1490, 1834, 3068, 3101, 3128, 3149, 3180, 3635

anti- $\mathrm{CH}_{3} \mathrm{COCHCl}$

122, 151, 214, 451, 491, 503, 661, 788, 941, 1013, 1044,

1263, 1338, 1418, 1479, 1487, 1650, 3074, 3132, 3180,

3254

syn- $\mathrm{CH}_{3} \mathrm{COCHCl}$

20, 1445, 213, 367, 502, 592, 629, 835, 945, 1010, 1042, 1207, 1376, 1414, 1482, 1490, 1678, 3068, 3127, 3175, 3239

anti- $\mathrm{CH}_{2} \mathrm{ClCOCH}_{2}$ 40, 237, 389, 418, 498, 500, 773, 805, 857, 930, 1024, 1208, 1301, 1313, 1463, 1479, 1574, 3129, 3186, 3191, 3308

syn- $\mathrm{CH}_{2} \mathrm{ClCOCH}_{2}$ 50, 216, 360, 366, 491, 576, 753, 779, 877, 929, 1015, 1199, 1204, 1353, 1465, 1477, 1648, 3102, 3151, 3173, 3289 